\title{
Field Efficacy of Certain Chemical Insecticides against Rice Leaf Folder, Cnaphalocrocis medinalis Guenee
}

\author{
Pramod Kumar Kaiwart", Ashwani Kumar, Hadi Husain Khan and Ramkinkar Sahu \\ Department of Entomology, Sam Higginbottom University of Agriculture, Technology and \\ Sciences, Allahabad, U.P., India \\ *Corresponding author
}

\section{A B S T R A C T}

The present investigation entitled "Efficacy of certain chemical insecticides against leaf folder, Cnaphalocrocis medinalis Guenee." was conducted during July, 2015 at Agricultural research farm, SHIATS, Allahabad. The occurrence of leaf folder commenced from $33^{\text {rd }}$ standard week (August $2^{\text {nd }}$ week) with an average $1.54 \%$ infestation. The leaf folder infestation increased and gradually reached peak level of $7.62 \%$ infestation at $38^{\text {th }}$ standard week (September $3^{\text {rd }}$ week). Thereafter, declined trend was observed due to fall of

\section{Keywords}

Insecticides, Rice (Oryza sativa), Rice leaf folder (Cnaphalocrocis medinalis), Seasonal incidence.

Article Info

Accepted:

21 August 2017 Available Online:

10 September 2017 maximum and minimum temperatures as optimum weather condition are decreasing. Therefore, Per cent infestation was positively correlated with the maximum temperature. Hence decline of temperature lead to the decline of the leaf folder infestation. The two sprays were taken for the management of leaf folder. The data on the percent infestation of leaf folder after first and second spray revealed that all the chemical treatments were significantly superior over control. Among all the treatments lowest per cent infestation of leaf folder was recorded in Monocrotophos (1.07) followed by Dimethoate (1.39), Fipronil (1.46), Imidacloprid (1.56), Malathion (1.80), Cartap hydrochloride (1.88), Spinosad (2.28) as compared to control (6.49). At pooled data all the treatments were at par with each other except control, but within this first four treatments i.e. Monocrotophos, Dimethoate, Fipronil and Imidacloprid were best superior treatments in the management of rice leaf folder. The yields among the treatment were significant. The highest yield was recorded in $\mathrm{T}_{1}$ Monocrotophos (43.500 q/ha) followed by $\mathrm{T}_{6}$ Imidacloprid (42.500 q/ha), $\mathrm{T}_{7}$ Dimethoat (40.400) $\mathrm{T}_{2}$ Spinosad (39.800), $\mathrm{T}_{5}$ Fipronil (39.600 q/ha), $\mathrm{T}_{3}$ Malathion (38.20 q/ha), $\mathrm{T}_{4}$ Cartap hydrochloride $(38.00 \mathrm{q} / \mathrm{ha})$ as compared to control $\mathrm{T}_{0}(25.500$ $\mathrm{q} / \mathrm{ha}$ ). When cost benefit ratio was worked out, interesting result was achieved. Among the treatment studied, the best and most economical treatment was $\mathrm{T}_{1}$ Monocrotophos (1:3.16), followed by $\mathrm{T}_{7}$ Dimethote (1:2.95), $\mathrm{T}_{6}$ Imidacloprid (1:2.82), $\mathrm{T}_{4}$ Cartap Hydrochloride (1:2.47), $\mathrm{T}_{3}$ Malathion (1:2.75), $\mathrm{T}_{2}$ Spinosad (1:2.38), T5 Fipronil (1:2.31) as compared to control $\mathrm{T}_{\mathrm{o}}(1: 2.03)$.

\section{Introduction}

Rice is the world's most important food cereal crop and a main food source for more than a third of the world's population. More than 90 $\%$ of the world's rice is cultivated and consumed in Asia where $60 \%$ of the world's people live. Rice provide about 35 to $60 \%$ of the calories consumed by 3 billion Asians (Khus, 1997). 
Rice leaf folder, Cnaphalocrocis medinalis (Guen. Pyralidae Lepidoptera) was considered as pests of minor importance have increased in abundance in late 1980's and have become major pests in many parts world (Ahmed et $a l ., 2010)$. Rice leaf folder is the most widely distributed and found foliage feeder in rice. An increase in $C$. medinalis population could be attributed to the large scale cultivation of high yielding varieties, excessive usage of nitrogenous fertilizers and continuous use of insecticides that created resistance against this pest. This insect has attained the status of major pest during the last few years (Shah et al., 2008).

\section{Materials and Methods}

The present investigation was conducted at the Central Research Farm of Sam Higginbottom Institute of Agriculture, Technology and Sciences, Allahabad, Uttar Pradesh during Kharif season 2015. To study the efficacy of newer insecticides trial was laid out in RBD block design with 8 treatments, replicated four times. The "IR6444" hybrid variety of rice was used and a healthy crop was raised by following all the recommended agronomical practices. The plot size was $5 \mathrm{~m} \times 5 \mathrm{~m}$ and the spacing between rows and plants was maintained at 20 and 10 $\mathrm{cm}$, respectively.

For efficacy of insecticidal treatments, the observations were recorded from 10 plants selected at random. Observations on the efficacy of newer insecticides were recorded before 1 day spraying and on $2^{\text {nd }}$ day, $7^{\text {th }}$ day and $14^{\text {th }}$ day after insecticidal application. Finally yield was recorded for every treatment to calculate cost benefit ratio.

\section{Results and Discussion}

The pests appeared on 32 standard week (August $2^{\text {nd }}$ week) on rice crop with an average infestation per cent 1.54 of leaf folder (Table 1). The leaf folder infestation increased and gradually reached peak level of 7.62 per cent on $38^{\text {th }}$ standard week (September $3^{\text {rd }}$ week). At that time, average max temperature was $35.65^{\circ} \mathrm{C}$ and minimum temperature was $28.05^{\circ} \mathrm{C}$, maximum relative humidity was $86.28 \%$ and minimum 55.71 $\%$, average wind velocity was $2.17 \mathrm{~km} /$ hour and average sun shine hour was 7.11 hours.

These findings can be supported with the work of Netam and Gupta (2015) and Kumar et al., (2013) who stated that the peak population was observed in $32^{\text {nd }}$ to $40^{\text {th }}$ standard week.

Ram et al., (2014) reported positive correlation between the pest population and maximum temperature in. Similarly, Chakraborty et al., (2011) reported the infestation of leaf folder showed negative correlation with rainfall and relative humidity in northern part of West Bengal.

The data on the pooled mean percent leaf infestation of first and second spray revealed that all the chemical treatments were significantly superior over control (Table 2). Among all the treatments lowest percent infestation of leaf folder was recorded in Monocrotophos (1.07), Dimethoate (1.39), Fipronil (1.46), Imidacloprid (1.56), Malathion (1.80), Cartap hydrochloride (1.88), Spinosad (2.28) as compared to control (6.49). Per cent infestation reduction of leaf folder recorded at $1^{\text {st }}$ and $2^{\text {nd }}$ spray after insecticidal applications of Monocrotophos was found significantly superior $(76.02 \%)$ followed by Imidacloprid $(68.67 \%)$ as compared to other treatments Dimethoate $(67.10 \%)$, Fipronil (66.53 \%), Cartap hydrochloride (64.83\%), Spinosad $(58.21 \%)$ and Malathion (58.68 \%) respectively. Similar findings have been reported by Alvi (2003), Dey (2012) and Chakraborty et al., (2011) (Table 3). 
Table.1 Seasonal incidence of rice leaf folder

\begin{tabular}{|l|l|l|l|l|l|l|l|l|}
\hline & & \multicolumn{2}{l|}{ Temperature } & \multicolumn{2}{l|}{ Humidity } & & & \\
\hline Weeks & $\begin{array}{l}\text { Infesta } \\
\text { tion \% }\end{array}$ & Max & Min & Max & Min & $\begin{array}{l}\text { Rain } \\
\text { fall }\end{array}$ & $\begin{array}{l}\text { Wind } \\
\text { velocity } \\
\text { (km/hr) }\end{array}$ & $\begin{array}{l}\text { Sunshine } \\
\text { (hr/day) }\end{array}$ \\
\hline $\mathbf{3 1}$ & 0.02 & 35.97 & 27.74 & 92.45 & 53.42 & 5.00 & 1.33 & 5.34 \\
\hline $\mathbf{3 2}$ & 1.54 & 34.22 & 27.42 & 92.35 & 52.36 & 0.00 & 1.25 & 5.12 \\
\hline $\mathbf{3 3}$ & 2.98 & 33.12 & 27.55 & 92.45 & 55.25 & 0.00 & 1.24 & 4.52 \\
\hline $\mathbf{3 4}$ & 3.45 & 33.22 & 27.00 & 92.85 & 58.28 & 12.48 & 1.28 & 4.80 \\
\hline $\mathbf{3 5}$ & 4.92 & 35.45 & 27.42 & 90.71 & 54.85 & 11.85 & 2.22 & 5.74 \\
\hline $\mathbf{3 6}$ & 5.80 & 36.42 & 27.20 & 89.71 & 45.42 & 0.00 & 2.55 & 7.97 \\
\hline $\mathbf{3 7}$ & 6.48 & 37.48 & 27.37 & 86.71 & 47.14 & 0.00 & 1.68 & 8.70 \\
\hline $\mathbf{3 8}$ & 7.08 & 35.65 & 28.05 & 86.28 & 55.71 & 0.60 & 2.17 & 7.11 \\
\hline $\mathbf{3 9}$ & 7.62 & 36.42 & 27.80 & 90.71 & 47.14 & 0.20 & 1.71 & 7.17 \\
\hline $\mathbf{4 0}$ & 6.02 & 36.11 & 27.80 & 89.00 & 50.14 & 0.00 & 1.84 & 8.45 \\
\hline $\mathbf{4 1}$ & 3.28 & 35.77 & 27.82 & 90.00 & 51.57 & 0.00 & 1.56 & 8.68 \\
\hline $\mathbf{4 2}$ & 2.89 & 35.85 & 23.88 & 78.28 & 51.40 & 0.00 & 1.35 & 8.57 \\
\hline $\mathbf{4 3}$ & 2.32 & 36.00 & 20.57 & 93.00 & 50.71 & 0.00 & 0.96 & 8.65 \\
\hline $\mathbf{4 4}$ & 1.21 & 35.25 & 19.71 & 91.57 & 29.71 & 0.64 & 0.71 & 6.65 \\
\hline $\mathbf{4 5}$ & 0.560 & 33.57 & 20.08 & 90.71 & 57.00 & 0.00 & 0.51 & 8.30 \\
\hline $\mathbf{4 6}$ & 0.250 & 32.22 & 20.18 & 89.42 & 52.21 & 0.18 & 0.48 & 8.54 \\
\hline $\mathbf{r =}$ & & .572 & -0.186 & -0.355 & -0.536 & -0.515 & -0.391 & 0.860 \\
\hline $\mathbf{t =}$ & & 2.698 & -0.732 & -1.471 & -2.461 & -2.325 & -1.643 & 6.532 \\
\hline & & $\mathrm{S}$ & $\mathrm{NS}$ & $\mathrm{NS}$ & $\mathrm{S}$ & $\mathrm{S}$ & $\mathrm{NS}$ & $\mathrm{S}$ \\
\hline
\end{tabular}

Table.2 Efficacy of certain chemical insecticides against rice leaf folder during kharif season 2015

\begin{tabular}{|l|c|c|c|c|c|c|c|}
\hline \multirow{2}{*}{ Treatment } & \multicolumn{7}{|c|}{ Leaf folder infestation percent per hill } \\
\cline { 2 - 9 } & $\begin{array}{c}\text { Pre- } \\
\text { treatments }\end{array}$ & 3 DAS & 7 DAS & 14 DAS & 3 DAS & 7 DAS & 14 DAS \\
\hline Control & 4.92 & 5.24 & 5.80 & 6.48 & 6.72 & 7.08 & 7.62 \\
\hline Monocrotophos & 5.86 & 1.28 & 1.48 & 1.96 & 0.48 & 0.52 & 0.69 \\
\hline Spinosad & 6.08 & 2.91 & 3.23 & 3.48 & 1.08 & 1.38 & 1.62 \\
\hline Malathion & 5.78 & 1.98 & 2.02 & 2.32 & 1.28 & 1.48 & 1.71 \\
\hline $\begin{array}{l}\text { Cartap } \\
\text { hydrochloride }\end{array}$ & 5.8 & 2.68 & 2.76 & 2.95 & 0.76 & 0.97 & 1.18 \\
\hline Fipronil & 5.87 & 1.98 & 2.08 & 2.21 & 0.67 & 0.82 & 0.98 \\
\hline Imidacloprid & 5.24 & 2.04 & 2.36 & 2.58 & 0.67 & 0.79 & 0.96 \\
\hline Diamehoate & 4.92 & 1.86 & 1.68 & 2.12 & 0.95 & 0.78 & 0.98 \\
\hline F- test & $\mathrm{NS}$ & $\mathrm{S}$ & $\mathrm{S}$ & $\mathrm{S}$ & $\mathrm{S}$ & $\mathrm{S}$ & $\mathrm{S}$ \\
\hline S. Ed. ( $\mathbf{(})$ & 0.34 & 0.19 & 0.13 & 0.25 & 0.20 & 0.17 & 0.25 \\
\hline C. D. $(\mathbf{P}=\mathbf{0 . 0 5})$ & 0.70 & 0.39 & 0.28 & 0.53 & 0.42 & 0.35 & 0.52 \\
\hline
\end{tabular}


Table. 3 Per cent population reduction of leaf folder $\left(1^{\text {st }}\right.$ and $2^{\text {nd }}$ Spray $)$

\begin{tabular}{|l|l|l|l|l|}
\hline \multicolumn{5}{|c|}{ Per cent population reduction per hill } \\
\hline & Treatment & $\mathbf{1}^{\text {st }}$ spray & $\mathbf{2}^{\text {nd }}$ spray & Pooled \\
\hline T0 & Control & 00 & 00 & 00 \\
\hline T1 & Monocrotophos & 77.91 & 74.13 & 76.02 \\
\hline T2 & Spinosad & 59.63 & 56.79 & 58.21 \\
\hline T3 & Malathion & 55.97 & 61.40 & 58.68 \\
\hline T4 & Cartap hydrochloride & 62.98 & 66.69 & 64.83 \\
\hline T5 & Fipronil & 68.20 & 65.05 & 66.53 \\
\hline T6 & Imidacloprid & 70.20 & 67.14 & 68.67 \\
\hline T7 & Diamehoate & 69.51 & 64.69 & 67.10 \\
\hline
\end{tabular}

Table.4 Pooled mean of leaf infestation by leaf folder during kharif season of 2015 and its effect on yield and cost benefit ratio

\begin{tabular}{|c|c|c|c|c|c|}
\hline \multirow[t]{2}{*}{ Treatments } & \multicolumn{2}{|c|}{ Leaf infestation per hill } & \multirow{2}{*}{$\begin{array}{l}\text { Pooled mean of } \\
\text { leaf infestation }\end{array}$} & \multirow{2}{*}{$\begin{array}{c}\text { Yield } \\
\text { of q/ha }\end{array}$} & \multirow{2}{*}{$\begin{array}{l}\text { Cost Benefit } \\
\text { ratio }\end{array}$} \\
\hline & Mean of $1^{\text {st }}$ Spray & Mean of $2^{\text {nd }}$ Spray & & & \\
\hline Control & 5.84 & 7.14 & 6.49 & 25.500 & $1: 2.03$ \\
\hline Monocrotophos & 1.57 & 0.56 & 1.07 & 43.500 & $1: 3.16$ \\
\hline Spinosad & 3.20 & 1.36 & 2.28 & 39.800 & $1: 2.38$ \\
\hline Malathion & 2.10 & 1.49 & 1.80 & 38.200 & $1: 2.75$ \\
\hline $\begin{array}{l}\text { Cartap } \\
\text { hydrochloride }\end{array}$ & 2.79 & 0.97 & 1.88 & 38.000 & $1: 2.47$ \\
\hline Fipronil & 2.09 & 0.82 & 1.46 & 39.600 & $1: 2.31$ \\
\hline Imidacloprid & 2.32 & 0.80 & 1.56 & 42.500 & $1: 2.82$ \\
\hline Diamehoate & 1.88 & 0.90 & 1.39 & 40.500 & $1: 2.95$ \\
\hline F- test & $\mathrm{S}$ & $\mathrm{S}$ & $\mathrm{S}$ & & \\
\hline S. Ed. $( \pm)$ & 0.485 & 2.165 & 1.148 & & \\
\hline C. D. $(P=0.05)$ & 1.029 & 4.590 & 2.434 & & \\
\hline
\end{tabular}

The yields among the treatment were significant. The highest yield was recorded in $\mathrm{T}_{1}$ Monocrotophos (43.500 q/ha) followed by $\mathrm{T}_{6}$ Imidacloprid (42.500 q/ha), $\mathrm{T}_{7}$ Dimethoate (40.400 q/ha) T2 Spinosad (39.800 q/ha), $\mathrm{T}_{5}$ Fipronil (39.600 q/ha), $\mathrm{T}_{3}$ Malathion (38.20 $\mathrm{q} / \mathrm{ha}), \mathrm{T}_{4}$ Cartap hydrochloride $(38.00 \mathrm{q} / \mathrm{ha})$ as compared to control $\mathrm{T}_{0}(25.500 \mathrm{q} / \mathrm{ha})$ (Table 4). When cost benefit ratio was worked out, interesting result was achieved. Among the treatment studied, the best and most economical treatment was T1 (1:3.16), followed by $\mathrm{T}_{7}(1: 2.95), \mathrm{T}_{6} \quad(1: 2.82), \mathrm{T}_{4}$ (1:2.47), $\mathrm{T}_{3}(1: 2.75), \mathrm{T}_{2}(1: 2.38), \mathrm{T}_{5}(1: 2.31)$ as compared to control $\mathrm{T}_{0}$ (1:2.03). The highest yield and benefit cost ratio was recorded in $\mathrm{T}_{1}$ Monocrotophos (43.500 $\mathrm{q} / \mathrm{ha}$ and 1:3.24 respectively) supported by Mahal et al., (2008), Devi and Singh (2016). Next most effective treatment was $\mathrm{T}_{6}$ Imidacloprid (42.500 q/ha and 1:3.18 respectively), this was supported by Devi and Singh (2016).

\section{Acknowledgement}

The authors are thankful to Head, Department of Plant Pathology, SHIUATS for providing necessary facilities during experiment. 


\section{References}

Ahmed, H., Khan, R. B., Sharma, D., Jamwal, V. V. S. and Gupta, S. 2010. Seasonal incidence, infestation and trap catches of Cnaphalocrocis medinalis (Guenee) in rice. Annals Pl. Prot. Sci. 18 (2):38383.

Alvi, S. M., Ali, M. A., Chaudhary, S. and Iqbal, S. 2003. Population trends and chemical control of rice leaf folder, Cnaphalocrocis medinalis on rice crop. Inter. J. Agric. Biol. 5 (4):615-617.

Chakraborty, K., and Deb, D. C. 2011. Extent of suppression of leaf folder, Cnaphalocrosis medinalis, Population by some selected insecticides in the field of scented local paddy cultivar Tulaipanji at raiganj, uttar dinajpur, West Bengal, India. International Journal of plant Animal and Environmental Sciences. 1 (3):142-148.

Devi, P.R., and Singh, K. S. 2015. Efficacy of new molecules, Spinosad and Monocrotophos on the incidence of rice leaf folder Cnaphalocrocis medinalis guenee umder kharif rice crop ecosystem on manipur valley. International journal of Agriculture.6 (1): 7-14.
Dey, U., Sarkar, B.B., Dhutraj,D. N. amd Badgujar, S. L. 2012. Efficacy of different insecticides for controlling the rice leaf folder (Cnaphalocrocis medinalis Guenee). Advanced research Journal of Crop improvement.3 (2):118121.

Mahal, M. S., Sarao, P.S. and Singla, M. L. 2008. Bioefficacy of Fipronil 800 WG for the Control of Stem Borer and Leaf Folder in Basmati Rice. Indian Journal of Plant Protection, 36 (2):260-262.

Netam, C.S., and Gupta, A.K. 2015. Seasonal incidence of leaf folder of rice in agro climatic condition of Baster plateau zone. Annals of Plant ans soil research 17 (1) 24-28.

Ram, M., Sachan S. K. and Singh, G. 2014. Study on population build-up of rice leaf folder Cnaphalocrocis medinalis in relation to weather factors. International journal of advanced research 2 (10):75-77.

Shah, S., Ali, M., Rehman, U. H., Rehman, A., Abbasi, F.M., Khalil, I.H. and Ali, A. 2008. Characterization of wild rice species in response to leaf folder (C.medinalis). Sarth. Journal of Agriculture 24 (1): 69-74.

\section{How to cite this article:}

Pramod Kumar Kaiwart, Ashwani Kumar, Hadi Husain Khan and Ramkinkar Sahu. 2017. Field Efficacy of Certain Chemical Insecticides against Rice Leaf Folder, Cnaphalocrocis medinalis Guenee. Int.J.Curr.Microbiol.App.Sci. 6(9): 1692-1696. doi: https://doi.org/10.20546/ijcmas.2017.609.208 